INTERACTIVE ARTICLE COVER

RUPKATHA JOURNAL

About the Journal

\begin{tabular}{|c|c|}
\hline \multicolumn{2}{|r|}{ About the Journal } \\
\hline Journal DOI & https://doi.org/10.21659/rupkatha \\
\hline Journal Home & www.rupkatha.com $\oslash$ \\
\hline Indexed by & Scopus Web of Science: Emerging Sources Citation Index (ESCI) DOAJ \\
\hline Journal Metrics & CiteScore 2020: 0.2 | SJR 2020: 0.162 | SNIP 2020: 0.193 | JCI 2020: 0.50 \\
\hline \multicolumn{2}{|r|}{ About the Issue } \\
\hline Themed issue & $\begin{array}{l}\text { Volume 4, number 1, } 2022 \text { (January-March) | Contemporary East and } \\
\text { Southeast Asian Literary and Cultural Studies }\end{array}$ \\
\hline Guest Editors & Dr Jeremy de Chavez $\triangle$ \& Dr Zhang Yue, University of Macau, China \\
\hline Issue DOI & https://doi.org/10.21659/rupkatha.v14n1 \\
\hline TOC & https://rupkatha.com/v14n1.php \\
\hline Peer Review & Under the responsibility of the Guest Editors \\
\hline \multicolumn{2}{|r|}{ About the Article } \\
\hline Title & $\begin{array}{l}\text { Apostol's Creed: Unveiling the Political Fictions of Colonialism and Nation in } \\
\text { the Diasporic Novel }\end{array}$ \\
\hline Author/s & Marikit Tara Alto Uychoco $\otimes$ \\
\hline Affiliation & University of the Philippines Diliman, Quezon \\
\hline Author ID & https://orcid.org/0000-0001-8087-870X \\
\hline Funding & No funding received. Published free of any charge. \\
\hline Article DOI & https://doi.org/10.21659/rupkatha.v14n1.15 Pages: 1-11 \\
\hline Abstract & https://rupkatha.com/v14n115 \\
\hline Full-text PDF & https://rupkatha.com/V14/n1/v14n115.pdf $入$ \\
\hline \multirow[t]{3}{*}{ Article History } & Abstract received: 8 Feb 2021 | Complete article received: 1 June 2021 \\
\hline & Revised article received: 12 August 2021 | Accepted: 6 Sept 2021 \\
\hline & First Published: 05 February 2022 \\
\hline Article Impact & Check Dynamic Impact $\oslash$ \\
\hline Copyright & Aesthetics Media Services $\square$ \\
\hline Licensing & Creative Commons Attribution Non-Commercial 4.0 \\
\hline
\end{tabular}

This Open Access article is published under a Creative Commons Attribution Non-Commercial 4.0 International License (http://creativecommons.org/licenses/by-nc/4.0/), which permits non-commercial re-use, distribution, and reproduction in any medium, provided the original work is properly cited. For citation use the DOI. For commercial re-use, please contact editor@rupkatha.com. 
1 Rupkatha Journal, Vol. 14, No. 1, 2022

Research Article

\title{
Apostol's Creed: Unveiling the Political Fictions of Colonialism and Nation in the Diasporic Novel
}

\author{
Marikit Tara Alto Uychoco \\ Department of English and Comparative Literature, University of the Philippines Diliman, Quezon \\ City, Philippines.
}

\begin{abstract}
Gina Apostol is a Philippine-American writer whose novel, Insurrecto, gives important insights into the political fictions of colonialism and the nation-state. Using postmodern readings of metafiction and historiographic metafiction, as well as postcolonial readings of hybridity and postcolonial doubles, this paper will unearth the political fictions that were used by the United States in rationalizing the PhilippineAmerican War, and the political fictions used by the Philippines in rationalizing extrajudicial killings. This paper follows the argumentation of Ania Loomba, who argues that nation-states have used the same violence as those used by colonizing powers, and that after the colonizing powers left, the nation-state excluded and silenced marginal peoples. Philippine-American Literature distinguishes itself against AsianAmerican Literature because it discusses the Philippine colonial experience under the U.S., lending itself to important reflections regarding hybridity, historiography, and solidarity. This paper will use the postmodern theories of Patricia Waugh when it comes to metafiction, Linda Hutcheon's and Michel Foucault's theories regarding historiographic metafiction and suprahistorical history, and the postcolonial theories of Homi Bhabha and Gloria Anzaldua regarding hybridity.
\end{abstract}

Keywords: Philippine-American Literature, Diasporic Literature, Metafiction, Historiographic Metafiction, Hybridity

\section{Introduction}

Gina Apostol's Insurrecto has many insights into the political fictions of the US colonial powers and today's Philippine nation-state. In writing a novel that confronts the socio-political fictions of American colonial history and the Philippine state, Apostol has managed to hit two birds with one stone. She describes the systematic violence of both colonialism and nationalism, using a postcolonial stance and postmodern methodologies. Although postcolonialism and postmodernism are often at odds with each other, this novel shows how they can work together to create a novel of postcolonial hybridity.

Gina Apostol is considered a Filipino-American writer and she has received several literary awards for her novels. For Insurrecto, she was a finalist for the Dayton Literary Peace Prize (Reinhardt University). When it comes to her novels, Apostol tells us, "It's not just being a Filipino or these identifiers that we have. There are multiple pulse points. And that might allow us to be more aware of being manipulated, aware of the authorship that others are doing to us. It's so 
important now because we have to be so much smarter about how we read, how we take in information" (Apostol, G., qtd. in Doll, J. 2020). Apostol's writing is found in Asian-American anthologies, but it is best to classify her under Philippine-American literature since her work delves into America's colonial influence in the Philippines (Ponce, Martin Joseph 2012).

Gina Apostol is also considered a postmodern writer. Unfortunately, this can make her a target of critical hostility. This hostility towards the postmodern sensibilities of Filipino-American writers was first articulated by E. San Juan, Jr., in his critique of Jessica Hagedorn's work, writing, "Addressed mainly to a cosmopolitan audience, Hagedorn's trendy work is undermined by postmodern irony: It lends itself easily to consumer liberalism's drive to consume everything (dreams, eros, the New People's Army, feminism, anarchist dissent) into an ensemble of selfgratifying spectacle" (88, Arming the Spirit, 1998). However, this paper would argue that the novel's postmodern sensibility does not blunt her postcolonial attacks, but calls for a new way of reading and being.

This paper argues that Apostol's work falls under revolutionary writing, which is tactical in its hope to create solidarity beyond borders. In writing about Gina Apostol's novel, The Revolution According to Raymundo Mata, Martin Joseph Ponce writes, "While this critique of U.S. imperialism provides one important link to readers in the United States, the novel also reaches toward a broader audience through its thematic clustering of reading, revolution, and resurrection" (2012, 231). According to Ponce, Philippine American literature can be described as "queer" since "Filipino literature in the United States is shaped by the overlapping forces of colonialism, imperialism, and migration. Situated between the Philippine postcolonial and the U.S. ethnic, what I describe as diasporic Filipino literature exceeds the boundaries of either national frame..." (2012, 2).

Because of this multiplicity of audiences, Philippine American literature has the potential for solidarity among different nationalities. This highlights what Bill Ashcroft would call the critical stance of "hope" coming from diasporic literature. Ashcroft discusses how diasporic writers can write about injustices in their origin country without fear of the nation-state's reprisal. This position frees diasporic writers in articulating what is often hidden or unsaid in the origin country (2020). This has been especially true in Apostol's Insurrecto. Her novel, which was published in 2019, tackles the extrajudicial killings under the Duterte administration and its Drug War. Given how the Philippine government under President Rodrigo Duterte has persecuted those who denounce these extrajudicial killings, her novel stands as a bold statement against the Philippine nation-state. Ashcroft's critical discourse of hope posits that even though diasporic writers no longer reside in the origin country, they still have the opportunity to help those at home. He tells us that, "home is no longer one place," and that he follows the belief that bell hooks wrote, how the concept of home is "part of a construction of a new world order" (hooks, quoted in Ashcroft, 2020).

How do these postcolonial articulations extend to literature from countries that are no longer colonized? Far from only limiting their postcolonial critiques to neo-colonial and colonial articulations of nations, they may also be extended to the nation-states that have found independence after the colonial powers have left. Ania Loomba discusses how the systemic oppression wielded by the colonizers of old are now wielded by nation-states; the state 
systematically excludes marginalized people using the law, education, bureaucracy, and the army. She writes how postcolonial writers have been critical of the idea of the nation as a liberating institution since there will always be those who will be marginalized by the state. Because of this, postcolonial writers can use the same tools used in decolonizing institutions towards the liberation of those marginalized by the state (2015).

In sum, Gina Apostol's novel, Insurrecto uses postcolonialism and postmodernity to reveal the political fictions wielded by empire and nation. It is a strategic move to educate readers regarding imperialist and nationalist propaganda, as well as a way to reach out to multiple audiences that might sympathize with the victims of U.S. colonialism and the Filipino Drug War. The novel shows us the political fictions of colonialism and the nation-state, not only through its content but through its postmodern form. The reading of the novel, as dictated by its form, is the message - and that is, one should question the frame, and hence, question the national or imperialist narrative, and hence, question the realities that we are faced with today.

\section{Postmodernity in Insurrecto: Metafiction and Historiographic Metafiction}

Insurrecto is a metafictional novel that asks the reader to participate in its unravelling. However, it is not only postmodern in style but postcolonial in its attack, as aptly described by Viet Thanh Nguyen, who writes at the back of the novel, "Gina Apostol... takes on the vexed relationship between the Philippines and the United States, pivoting on that relationship's bloody origins. Insurrecto is meta-fictional, meta-cinematic, even meta-meta, plunging us into the vortex of memory, history, and war" (qtd. in Apostol 2019). The novel's project of memorializing the deaths of the Balangiga Massacre by the U.S. Military and those of the extrajudicial killings in the Philippine Drug War, is a laudable one, and it is made even more remarkable because of its postmodernity.

For us to understand the novel further, it would be helpful to understand what postmodern metafiction is. According to Patricia Waugh, metafiction is self-conscious fiction; it makes the reader pay attention to its constructed nature and asks larger questions about the constructed nature of the world. Eventually, the metafictional writer wants the reader to realize that the world is filled with multiple fictions that construct it and that readers can challenge and question these fictions. Metafiction does this using frames - showing how novels, as well as the real world, are constructed (Waugh, 1984). In novels, a framing device would be the strategy of having stories within stories, like the Russian nesting dolls - a technique used by William Shakespeare in Hamlet when he placed a play within a play (1998).

Another metafictional device is the use of frame breaks, where the illusion of the continuous frame of fiction is shattered, making the reader realize that the continuous frames of the real world and history are, just like fiction, illusions based on constructed fictions (Waugh 1984). For example, in the novel Don Quixote by Miguel Cervantes, the novel discusses the book Don Quixote and the author Miguel Cervantes; it has a dialogue between Don Quixote and Sancho Panza about their subsequent literary fame and their many readers, which is why in this novel, "Levels of reality are blurred. A reader enters the book and becomes a character. The main 
4 Apostol's Creed: Unveiling the Political Fictions of Colonialism and Nation in the Diasporic Novel

characters learn about their book, and, in essence, become readers of their book" (Richardson 2014).

Apostol uses these metafictional strategies in Insurrecto. As a framing device, she has two scripts in the novel, from the contrasting viewpoints of the Filipino protagonist, Magsalin, and of her American friend, Chiara. She has two novels in the novel - one by Stéphane Réal and one by Magsalin, where she begins her "novel" with the creation of a character named Chiara. These framing devices prepare you for the frame breaks - and the frame breaks show us that the insights in these stories apply to the real world, as well.

The realization that Chiara is a character created by Magsalin is a frame break. Upon first reading, the reader might not realize that Chiara is a fictional character created by Magsalin; Chiara seems like a fully fleshed character in Insurrecto. However, after multiple readings, one will eventually see the clues that show that Chiara is not quite there-she is more ethereal than flesh, more memory than reality. Paying attention to these frame breaks allows the reader to appreciate how the American friend, or the Colonizer, is a fictional creation of the Colonized. This subverts the usual orientalist ${ }^{\mathrm{ii}}$ narrative, wherein it is usually the Colonizer who creates a fictional Other.

In another frame break, the novelist, Magsalin (who is the stand-in for the author) wonders whether she is being too clever for her good. Apostol writes, "that is, a writer dies. He dies in a vaguely political way, in the way in a colonized country only the political seems to have consequence. .. And if anything happens to her protagonist, who would be to blame" (98). The self-consciousness of the novelist in the narrative mirrors the self-consciousness of Apostol, who acknowledges the dangers of writing about the Duterte Drug War in today's political climate.

The novel goes into historical events, specifically the Balangiga Massacre in US-Philippine history, as well as current events, such as the Duterte Drug War, making the discussion of historiographic metafiction suitable for the novel's analysis. According to Linda Hutcheon, historiographic metafiction is fiction that makes us notice and question the constructed nature of history. History is a narrative that is neither neutral nor objective, even though it expresses itself as objective. It is always built upon ideological assumptions that articulates the dominant power's interpretation of events while silencing its marginal interpretations. It shapes meaning out of the events and the meaning is created and narrated by those in power (Hutcheon, L., 1988).

In the case of Insurrecto, these narratives are those that benefit the US colonial powers and the Duterte administration. Apostol portrays, not only the constructed nature of history but the constructed nature of the news and mass media. The juxtapositions between US colonial history in the Philippines and the Duterte Drug War tell us how these articulations of power rationalize death and violence on a massive scale.

Michel Foucault writes that there are three ways to subvert traditional history, which he also calls "suprahistorical history" - a history that masquerades as objective and universal. He writes, "Nietzsche's version of historical sense is explicit in its perspective and acknowledges its system of injustice. Its perception is slanted, being a deliberate appraisal, affirmation, or negation..." $(90,1984)$. Foucault tells us that it is possible to oppose this sense of history through parody, disassociation, and sacrifice. Parody is used to take away history's often exalted and sacred space - as eternal holders of truth - and to unmask it as a narrative with an agenda. Secondly, 
one can oppose history by using disassociation; accepting the gaps of our narratives and its discontinuities and acknowledging the incomplete nature of our identities, to open oneself to multiple interpretations of history. Thirdly, one can use sacrifice, by showing how history and its "will to knowledge" is rooted in injustice and violence while portraying itself as neutral and objective (Foucault, M., 1984).

Apostol uses all three strategies. Parody is found in her description of historiography regarding the Balangiga Massacre ${ }^{\mathrm{iii}}$. In one chapter, Magsalin looks at photographs from the U.S. Library of Congress, "pictures of banana groves, dead bodies in grey trenches, GIs in dress fatigues gazing down as if in regret at a charred background" $(80,2018)$. She discusses how one finds the photos in the U.S. Library of Congress website, with the phrase "Philippine insurrection," and how these phrases are problematic, writing, "'Insurgents' are in quotes. Insurrection is not. Rebel is a problematic term" "(81). The camera lens in the novel becomes the eye of the viewer (and in the case of the novel, the reader), which Apostol describes:

there is the eye of the colonized viewing their captured history

in the distance created by time;

there is the eye of the captor, the soldier, who has just wounded

the captured;

there is the eye of the captor, the Colonizer who has captured

history's lens;

there is the eye of the citizens, bystander, belligerent, blameless,

blamed, whose history has colonized the captured in the

distance created by time $(82,2018)$.

The quote tells us that history captured in photographs do not exist in a vacuum. The quote uses Foucauldian parody to show us how US history is slanted towards an imperial agenda.

Disassociation is seen in the multiple frame breaks of the novel, showing the gaps in the narrative, and opening itself up to interpretation. It tells us that real life, like the novel, is not a seamless narrative that is but is a socio-political construct. The reader constantly wonders who the narrator of the chapter is, since the novel shifts narrators without warning. There is a constant interruption different from the usual experience of reading the novel, a constant reminder that the world is framed through multiple perspectives.

The sacrifice of the will to knowledge is seen in many parts of the novel, wherein the "truths" of history are exposed as slanted versions of events. Chiara and Magsalin discuss history, where Chiara calls the Filipinos who killed the U.S. soldiers as insurrectionists, while Magsalin tells her they were revolutionaries. History is thus seen through two different perspectives. From the U.S. imperial perspective, the Filipino fighters were going against their country and hence, were considered insurrectionists, while from a Filipino perspective, these fighters were heroes fighting in the Philippine American War, and hence, revolutionaries. 
6 | Apostol's Creed: Unveiling the Political Fictions of Colonialism and Nation in the Diasporic Novel

\section{Postcolonial Doubles and Hybridity: Colonizer/Colonized}

The novel shows us that the colonizer and the colonized are not just different perspectives but are two sides of the same coin that forms a complete picture of history. In the discussion of the stereograph, a surgeon discusses human eyesight, saying, "Our vision is imperfect, only surmise. A disparity exists between the sight observed by the right eye and by the left... In order to see correctly, the mind must compute... Our mind imagines. That is how we see. Through illusion" (Apostol 159, 2018). This scientific discourse creates the argument that both the Colonizer and the Colonized eyes are needed to see the world completely, and that it is only through the imagination, which fills in the blanks between the gaps of perception, can we see the world whole.

Doubles and doubled vision, as a theme, runs throughout the novel. It is important to understand the postcolonial importance of doubles, as discussed by Homi Bhabha, who writes about the colonial experience, wherein one "can never attain the whiteness he has been taught to desire, or shed the blackness he is learned to devalue" (Loomba, 2015). Bhabha tells us that the colonial experience is "a doubling, dissembling image of being at least two places at once, which makes it impossible for the devalued, insatiable evolué... to accept the colonizer's invitation to identity... It is not the Colonialist Self or the Colonized Other, but the disturbing distance in between that constitutes the figure of colonial otherness - the White man's artifice inscribed on the Black man's body. It is in relation to this impossible object that emerges the liminal problem of colonial identity and its vicissitudes" (qtd. in Loomba, 2012, 175).

Gloria Anzaldua, in her poetics of Borderlands/La Frontera: The New Mestiza, discussed the importance of healing between the Colonizer and the Colonized and the birth of a hybrid perspective, "At some point, on our way to a new consciousness, we will have to leave the opposite bank, the split between the two mortal combatants somehow healed so that we are on both shores at once, and, at once, see through serpent and eagle eyes" (1987). Homi Bhabha discussed hybridity as a site of resistance, creating a new kind of politics with overlapping borders, with the revelation of the silencing done in history that paves the way towards new perspectives and identities (qtd. in Smith, 2004).

One segment shows how this doubling can happen within one person, as seen through Magsalin, writing: "In America, she kept confronting these doubles, cultural puns - repetitions of details from her homeland that have reverse or disjoint significance in this simultaneous place... One is in the other and the other is in the one... Her self overdubbed, multiplied, intercut, and hyperlinked..." (124-125, 2018). The doubling that occurs is undeniably postcolonial and hybrid, describing the experience of the Filipino-Americans.

The relationship between Colonizer and Colonized is also portrayed as sexual intercourse between the Filipina revolutionary Casiana Nacionales and the U.S. soldier, Frank Betron, where sex is "a simultaneous assault, one upon the other... It is a rocking, sighing braid of a shadow, a beast of a snake with twin heads, back and forth, back and forth in the talahib $(268,2018)$ ". In the end, it is Casiana Nacionales who saves the day; she is the titular Insurrecto who seduces Frank and steals his keys to the makeshift prison of guerilla fighters, which eventually allows the Filipinos to ambush the American soldiers in Balangiga. It is Cassiana's knowledge of Frank's weaknesses that opens the opportunity for resistance and the temporary Filipino victory over the U.S. military. 


\section{Literary and Political Fictions}

The postcolonial content of the novel, which attacks the oppressive practice of both US Empire and Filipino nation-state, informs the reader that the postmodern reading practices found in the novel (questioning realities and histories as seen in metafiction and historiographic metafiction) are important ways to view the world.

In Insurrecto, the political fictions that rationalize the Drug War of President Rodrigo Duterte are placed side by side with the reflections of Chiara and Magsalin, both of whom are horrified at the extrajudicial killings of drug addicts and suspects. In this manner, the nation-state's propaganda about the Drug War is disputed by the novel's main characters, where they tell the readers how wrong-headed the Drug War is, with Chiara stating, "...the country has been an icon of extrajudicial horror, a dystopia of brazen exterminations even in broad daylight, an international emblem of criminal slaughter by fascist police" (Apostol 2018, 69).

There are two instances of people riding in tandem on a motorbike in the novel, one where Chiara is almost kidnapped and another where she is almost caught by the Philippine National Police. In the first instance, the motorcycle "beeps an onomatopoeic tokhang tokhang tokhang, and the motorbike whizzes away" (72). The word tokhang alludes to the government's Drug War, which the Duterte government introduced as Oplan Tokhang, wherein the police would knock on the doors of suspects to investigate them. However, this has become a national policy that has allowed for thousands of extrajudicial killings. The Drug War and its extrajudicial killings are discussed in an article entitled "Governing through Killing: The War on Drugs in the Philippines," in the Asian Journal of Law and Society by David T. Johnson and Jon Fernquest:

In January 2018, Philippine police acknowledged that approximately 4,000 suspected drug users or sellers had been killed in the war on drugs, while Human Rights Watch put the number at 12,000 and Philippine human rights advocates claimed it was more than 16,000. Despite thousands of slayings, only a handful of investigations have occurred, and not a single government official has been convicted (2018).

Currently, the Philippine Drug War is being investigated by the International Criminal Court as a crime against humanity. According to Param-Preet Singh, "head of the Philippine Department of Justice, Menardo Guevarra, admitted police culpability in thousands of 'drug war' killings. But while the new police chief, General Guillermo Eleazar, has promised to cooperate with the Department of Justice, he is only allowing access to 53 case files" (2021).

In the novel, Magsalin describes how such a drug war could thrive in the Philippines, discussing how her three uncles support it:

It has slowly dawned upon her that her uncles voted for the current unspeakably perverse despot. Every night they gravely nod their heads, likewise and worldly Stoics, at the words of their leader, the drug-war obsessed macho who has voted to kill every criminal in sight.

"Only addicts are harmed, don't you worry, inday," Tio Ambrosio tells Magsalin as once again they watch more news of the dead bodies after dinner, piling up at the garbage 
8 Apostol's Creed: Unveiling the Political Fictions of Colonialism and Nation in the Diasporic Novel

dumps, in the slums, near schoolyards, and on all the monotonous commercial streets of the country - bodies upon bodies. "Are you a criminal? A drug lord?"

"No," she says.

"Then nothing to fear, inday! He is doing it to keep us all safe!" crows Tio Exequiel (113).

These articulations are familiar to the Filipino reader as they are often in social media. They echo Duterte's campaign material that was popularized when he campaigned for President. The notion of the need for the iron fist and the dehumanization of drug suspects is a popular formula that has proven effective for Duterte.

The Colonizer/Colonized divide between Chiara and Magsalin eventually disappear, especially when there is a need for solidarity against the nation-state. This is seen when Chiara is accused of having illegal drugs in her bag and narrowly escapes being arrested. This happens after Chiara finds a dead father and child on the road, "The blood keeps seeping away from their bodies, a hyperbolic dark shadow, an excessive notation of their fall that soon will encompass all - palms, jungle, nation, ocean" (Apostol 2018, 242). The boundaries of the crime are larger than the two victims, a crime that encompasses nations and oceans, and the solidarity needed to stop it are those that transcend traditional borders.

Magsalin saves her, telling the police that the drugs they accuse Chiara of having are her husband's ashes. One of the policemen finds himself uneasy at the idea of a cremated body, thinking, "Bodies are rotting, soiled, and waiting for his percentage, at the funeral parlor, at the drug war scenes. He is a Christian man, that is not a Christian body" (Apostol, 2018, 262). This summarizes what has been reported in the news, which tells us that the police are given rewards for meeting a quota of extrajudicial killings. According to Manuel Mogato and Claire Baldwin of Reuters, "The Philippine police have received cash payments for executing drug suspects, planted evidence at crime scenes and carried out most of the killings they have long blamed on vigilantes".

After tackling political fiction, we tackle the literary fiction of Chiara's character. Why is the imagined character of Chiara in the novel? At the end of the novel, in a discussion about Cassandra Chase in the script and an allusion to Chiara's (non)existence in the novel, Chiara asks Magsalin why she included Chase, "The white saviour story, I don't get that" (Apostol 2018, 291). Magsalin answers her:

"I did it for you," says Magsalin. "It's the only way you could have read the story."

The filmmaker falls silent.

Then Chiara says, "You tricked me." (Apostol 2018, 292)

Apostol uses this metafictional strategy to create a spotlight for stories that this audience (the cosmopolitan, consumerist west) would have otherwise ignored. This fictive alliance between an imaginary white friend and a real brown protagonist is a construct that hopes to be replicated outside of the frame. Given the metafictional nature of the novel, we see how this same trick was used by Gina Apostol, in having Chiara witness the story of the Filipino dead. 


\section{Conclusion}

In Insurrecto, Gina Apostol wants us to leave the frame of the novel and go to the larger frame of the world. Magsalin asks a question that resonates with the reader, "I mean, what the fuck is the point of knowing history's goddamned repetitive spirals if we remain its bloody victims?" (Apostol, $2018,50)$. The repetitive spirals are not only seen in the novel but in the real world, as well.

Chiara furthers this discussion, as she discusses the movie she would like to direct. Upon reading, the readers find that Apostol is writing about them, "I would like to make a movie in which the spectator understands that she is in a work of someone else's construction... We enter others' lives through two mediums, words and time, both faulty. And still, one story told may unbury another, and the dead, who knows, maybe resurrected. At least, that is the hope" (Apostol, 2018 , 51). In this case, the "construction" is the socio-political fiction that makes up history, politics, and reality.

The novel was always about leaving the frame and finding solidarity. When Apostol writes about meeting each other through "words and time," she is talking about the novel and the world, and how the novel might nudge the world to be. The novel argues for a new way of reading and a new way of being. It is insurrectionist, it is revolutionary, it is patriotic, it is traitorous; it is a novel that acts as a fulcrum that hopes to move the world.

\section{Declaration of Conflict of Interests}

The author(s) declared no potential conflicts of interest.

\section{Funding}

No funding has been received for the publication of this article. It is published free of any charge.

\section{Notes}

\footnotetext{
'Ponce defines "queer" as "in its expansive theoretical sense that denotes not a positivist essential category of homosexual identity, but an unraveling of the narrative lineup of biological sex, gender, and sexuality" $(2012,26)$, as well as the use of "queer" as an adjective to mean "uncertain," that "connotes both desire and inquiry, a mode of seeking knowledge that is itself driven by a practice of questioning unconsoled by fixed origins - a fitting analytic for exploring expressive forms produced by those not only rendered 'structurally queer' by U.S. imperial racialization but also questioning and in quest of identity" $(2021,27)$.

ii Orientalism in this sense, deriving from Edward Said's book Orientalism (1978), which is described thus, "Orientalism questions the very foundations of Western representation and the social construct of the 'Orient' as the ultimate Other in history, literature, art, music, and popular culture" (Burney 2012, 23).

iii Apostol gives a good summary of the Balangiga Massacre in the novel: "An uprising of Filipinos against an American outpost in Samar... leads to forty-eight American deaths, with twenty-two wounded and four
} 
missing in action... The U.S. commanding general demands in retaliation the murder or every Filipino male in Samar above ten years of age. Blood bathes the province. Americans savage - "kill and burn" is the technical term - close to thirty thousand Filipinos, men, women, and children, in a rampage of such proportions that the court-martial of the general, Jacob H. "Howling Widerness" Smith, causes a sensation when events become public in 1902" (2018).

\section{References}

Apostol, G. 2018. Insurrecto. New York: Soho Press.

Anzaldua, G. 1987. Borderlands/La Frontera: The New Mestiza. San Francisco: Aunt Lute Books.

Ashcroft, B. 2020. "Keynote Address: Diaspora Futures". The 2nd International Conference on Literature. Malaysia.

Burney, S. 2012. CHAPTER ONE: Orientalism: The Making of the Other. Counterpoints, 417, 23-39. Retrieved August 11, 2021, from http://www.jstor.org/stable/42981698

Doll, J. Poster October 16, 2020. "With 'Raymundo Mata,' Gina Apostol Gets Meta". Publisher's Weekly.

https://www.publishersweekly.com/pw/by-topic/authors/profiles/article/84636-with-raymundo-matagina-apostol-gets-meta.html. Accessed May 20, 2021.

Foucault, M. 1984. "Nietzsche, Genealogy, History." The Foucault Reader. Ed. Paul Rabinow. New York: Pantheon Books.

Johnson, D. and Fernquest, J. November 2018. "Governing Trough Killing: The War on Drugs in the Philippines". Asian Journal of Law and Society. Vol. 5, Issue 2, November 2018. DOI: https://doi.org/10.1017/als.2018.12. Date accessed: May 24, 2021.

Harvard Health Publishing. Posted March 22, 2021. "Double Vision (Diplopia)". Harvard Health Publishing. https://www.health.harvard.edu/a to z/double-vision-diplopia-a-toz\#: : :text=Double\%20vision\%2C\%20also\%20called\%20diplopia,the\%20other\%20eye\%20is\%20covere d. Accessed May 20, 2021.

Hutcheon, L. 1988. "Historiographical Metafiction: The Pastime of Past Time". A Poetics of Postmodernism: History, Theory, Fiction. London: Routledge.

Loomba, A. 2015. Colonialism/Postcolonialism. New York: Routledge.

Mogato, Manuel and Baldwin, Claire. Posted April 18, 2017. "Special Report: Police describe kill rewards, staged crime scenes in Duterte's drug war". Reuters. https://www.reuters.com/article/us-philippinesduterte-police-specialrep-idUSKBN17K1F4. Accessed August 12, 2021.

Ponce, M. 2012. Beyond the Nation: Diasporic Filipino Literature and Queer Reading. New York: New York University Press.

Reinhardt University. "Master of Fine Arts Writer: Gina Apostol". Reinhardt University. https://www.reinhardt.edu/academics/graduate-programs/mfa-cw/mfa-cw-faculty-staff/mfa-cw-ginaapostol/. Accessed May 20, 2021.

Richardson, Ronald B. Posted April 3, 2014. "Don Quixote: The Origin of Modern Realism and Metafiction". ronaldbrichardson.com. http://ronaldbrichardson.com/metafiction/don-quixote-the-origin-of-modernrealism-and-metafiction/. Accessed August 11, 2021. 
11 | Rupkatha Journal, Vol. 14, No. 1, 2022

San Juan, E. 1998. "Arming the Spirit, Writing in Times of Emergency". From Exile to Diaspora: Versions ofthe Filipino Experience in the United States. Quezon City: Ugnayan Para sa Makabayang Kamulutan.

Shafer, Jack. Posted on August 30, 2010. "Who Said It First? Journalism is the "first rough draft of history".

Slate.com. https://slate.com/news-and-politics/2010/08/on-the-trail-of-the-question-who-first-said-orwrote-that-journalism-is-the-first-rough-draft-of-history.html. Accessed August 11, 2021.

Shakespeare, W. 1998. "The Project Gutenberg eBook of Hamlet, by William Shakespeare". Project Gutenberg. https://www.gutenberg.org/files/1524/1524-h/1524-h.htm. Date Accessed: June 1, 2021.

Sikh, Param-Preet. Posted June 14, 2021. "ICC One Step Closer to Probe of Philippines Murderous 'War on

Drugs'". Human Rights Watch. https://www.hrw.org/news/2021/06/14/icc-one-step-closer-probephilippines-murderous-war-drugs. Accessed August 12, 2021.

Waugh, P. 1984. Metafiction: The Theory and Practice of Self-Conscious Fiction. London: Routledge.

\section{Author's bio-note}

Marikit Tara Alto Uychoco is an Assistant Professor from the Department of English and Comparative Literature of the University of the Philippines. She graduated with a Bachelor of Arts Degree in English, Major in Creative Writing, and a Master of Arts in Education, Major in English Language Teaching. She is currently studying for her PhD in Comparative Literature at the same university. Her research interests include historiographical metafiction, comparative literature, feminist theories, and postmodernity. 